\title{
The Rubik's Cube of Human Nature: a Reading of Dystopia in Divergent
}

\author{
Jiajun Xiong \\ College of Foreign Languages, Hunan University, Changsha Hunan China
}

\begin{abstract}
Divergent is a science fiction full of youth imprinted anti-utopian theme. The fiction reminds us the imbalance of modern technology and human development in the world, showing how the development of modern science and technology impact on the inherent existence of human nature. Alienation of the free will reveals the opposition of science and human nature. The idea to use modern technology to create "perfect world "is extremely dangerous and horrible, which is the extreme repression and destruction of human nature. Therefore, modern science and technology should be the evolution of human nature as the basic trend. Most studies focus on the topics of youth and spirit of resistance, some of the studies also involve the dystopian spirit, but few of them focus their studies on specific aspect of dystopia. This paper gives a detailed analysis on how this youth novel embodied the dystopia theme through the aspect of human nature.
\end{abstract}

Keywords: Dystopia; Divergent; Human Nature

\section{INTRODUCTION}

As an old Chinese saying goes, "Men have eight characters: kindness, loyalty, candor, faith, wisdom, valiant, greed and foolishness." The human nature is as complex as Rubik's cube in which each of the six faces is covered by nine stickers with six solid colors. In order to solve the puzzle, each face must be returned to have only one color. But we can never simplify the puzzle by smearing the faces with only one color, which may deprive the intrinsic meaning of puzzle game. But in Divergent (2011), the survivors of doomsday are divided into five factions according to their sole aptitude. And beneath the feint of harmony, the bud of dystopia is about to break through the soil.

As the debut novel of American novelist Veronica Roth, Divergent, which was published by HarperCollins Children's Books in 2011, has received mostly positive reviews. The book debuted at number six on the New York Times Children's Chapter Books Best Seller list on May 22, 2011, and remained on the list for 11 weeks. The novel is the first book of the Divergent trilogy, a series of young adult dystopian novels set in the post-apocalyptic version of Chicago. On the barren land of Chicago, the citizens, the survivors of global warfare which was caused by the freewill alter of human gene, were divided into five fragmented communities based on an aptitude test. There are five factions: Abnegation, taking selfless as the highest state and devote themselves to helping others; Amity, averting conflict with might and main; Candor, upholding integrity and truth and taking the world either black or white; Dauntless, seeking courage and protect the city at full split; and Erudite, regarding the knowledge as the root of all and keeping pursuing the truth of law of objective world. Each of the five factions perform their own functions to maintain the harmony. The founder thinks of the differences inside the human individuality as the source of war, and the existence of five factions can eradicate the evil. The governing faction sternly follows the "tradition" given by founder out of the thirst for peace. Each year, all sixteen-year-olds take an aptitude test that determines the faction for which they are best suited. After receiving the results, test-takers choose a faction at the Choosing Ceremony, no matter what their results are. Those who do not complete initiation into their new faction become "factionless" and are forced to live in poverty on the streets of the city.

Beatrice Prior, a daughter of Abnegation family, doesn't feel she belongs to her faction because she doesn't take selflessness as one of her innate trait. The result of her aptitude test is, in some sense, 
unfortunate, because it indicates she has the aptitude for three factions-Abnegation, Erudite, and Dauntless. The test administrator, Tori, warns her never to tell anyone that her results of the test as this marks her as "Divergent". As the symbol of "undefined" and "uncontrollable", Divergent is the pronoun of revolution, acting like the threat of the city. Every single one of Divergent shall be eradicated, because the leader of Erudite adopts the thought that the biggest enemy against the peace of the city is human nature. "Faction before blood" keeps everyone loyal to their factions, even if it means farewell to their families. On Choosing Day with a swinging heart, Beatrice decides to leave Abnegation and join Dauntless, and her brother Caleb chooses Erudite. After the sanguinary training in Dauntless, "Beatrice" changed her name into "Trice" and step on the road to demystify the secret of Divergent and disclose the veil above the false peace. It turns out that the "perfect world" is not that perfect and the massacre and revolt are concealed beneath the peaceful world. The hideous side of human nature never disappears, instead, it is kept deep down and attempts to break out one day to wreck the world.

As a youth dystopian fiction, Divergent gives a strong power to the readers to face difficulties and overcome personal weaknesses. It focuses not only on the growth of heroine but also the discussion of human nature and the caution about the unbalanced progress of modern science and technology. The development of science and technology shocks the existing form of human nature and the free will. The arbitrariness of science and technology results in the antagonism between technology and humanity. The attempt to build a utopia with modern technology is extremely dangerous, which undoubtedly causes repression and devastation to humanity. Therefore, the development of modern science and technology should follow the accordance of the revolution of human nature. As we can see, the implication of dystopia is deliberately embedded in this sci-fiction.

\section{DYSTOPIA AND YOUTH DYSTOPIA}

We comprehend the mirage of perfect world in Utopia by Thomas More and The Republic by Plato like "shared property", "all man is equal", "distribution according to one's needs". The happy life and richly endowed country are promised to the bright future and become the dynamic of human being to keep fighting for the Eden. However, the faultless utopia does not come true with the development of the world, on the contrary, people actually feel a sense of spiritual and psychological crisis that simultaneously comes with the benefits brought about by the evolution of modern science and technology. In the 20th century, some western authors abandon the yearning and depiction of the ideal world and drop their ink upon the caution about a gloomy world of dystopia. They try to express their resistance to the nightmare of dystopia world and release the sign of introspection about the alienation and distortion of human nature.

In The Quest for Utopia (Patrick, 1952), he creatively used the world "Dystopia" and thought the imaginary world created by Joseph Hall in A New World, and yet the Same (1605) is the opposite of utopia, which also appeared in Erewhon (1872) and Brave New World (1932). Thereout, the dystopian fiction entered the collective vocabulary as a new literary form. In this kind of fiction, people in the story always try to find a perfect way to build a pure world, but all these attempts are bound to fail no matter how beautiful the vision are. The crazy searches for the absolute pure world all lead to the deprivation and devastation of human nature, and the ravage and tread on liberty.

A new sub-genre of dystopian fiction, called "youth dystopian fiction", which combines the youth story and dystopian social context, is on the upgrade in the 21 th century. The very name suggests that in this kind of dystopian fiction, teenagers become the protagonist of the story, such as The Hunger Game trilogy (Year of Publication) and The Maze Runner trilogy (Year of Publication). Comparing with the traditional dystopian fiction, the leading character is often a teenager and the characterization mostly focus on adolescence, and romantic love is the derivative. Different from the repression and darkness in the traditional dystopian fiction, the undaunted courage revealed from the teenagers fighting against the darkness, the indomitable vitality and everlasting fighting will can be felt in the story, which encourage people to fight, surpass and save the hope in the dark future. 


\section{Alienation of Human Nature and Scientific And Technological Development}

Science and technology does not set human beings free, instead, it overrides, dominates people and even declares the extermination of mankind. The technological rationality fails to correct the evil side of human nature; conversely, the fundamental value is erased, and everything promised by the science, technology and reason turns out to be the nightmare of future. And the perfect world people painstakingly pursue becomes extremely absurd and dangerous.

In Divergent, the highly developed modern technology can concrete the thoughts of human being and display the scenes on a screen. More than that, the emotions, feelings, intuitions and even images can be simulated as long as the conner swallows a little tube of transparent liquid, which is also how the aptitude test runs. According to the five aptitudes, everyone shall be distributed to a decided faction with only one aptitude, and those who owns more than one aptitudes will be exiled with the label of revolt-Divergent. Superficially, every single one in this city finds where he or she belongs to and the meaning of life; substantially the whole system is designed to enslave and depress the human nature.

According to Marxism anthropology, we can comprehend that humanity is the natural quality, social attribute and spiritual attribute that comes with the practical activities when human being acts with nature, society and itself. Go without saying, social attribute is at the core position and spiritual attribute dominates and governs the operational process of human nature system. Like what I have mentioned before, humanity is like a Rubik's Cube which has six faces covered by nine stickers, the goodness and evil, the flesh and spirit, the sensibility and rationality and all of these makes man a man. What characterizes man is the richness and subtlety, the variety and versatility of his nature. Even today, known as the almighty power, science and technology is far from mastering the interaction mechanism of all factors in human nature system. The aptitude of human beings is not unidimensional as that in Divergent, but rather they are multi-dimensional. Different people are endowed with different natural talents, capacities, potencies and emotions, which brings up different humanities and constitutes the diversity of society. Therefore, even though we try to manipulate the variation of humanity for good, the differences among people can never be eliminated.

As a representative image of advanced technology, the scenario simulation rudely classifies people in an ultra way and attempts to achieve the efficient management of the citizens in Chicago and ignores human beings' inherent emotions and thoughts. Without the understanding that the complexity and diversity of human mind makes man a man, the simple classification of people can lead to horrible consequences. As the story tells us, the citizens in Chicago are classified according to their single aptitude, and the regulator just rigidly sticks to the belief that monotonous regularization will maintain the false peace. However, the mechanical operation of social management decomposes human nature, and the weaknesses of human nature that hides in the factions will come to light eventually.

Everybody is born with a heart for beauty, and we are all entitled to resist uniformity, but in Abnegation, you should never attach great importance to yourself.

“...She is well-practiced in the art of losing herself. I can't say the same of myself. I sneak a look at my reflection when she isn't paying attention-not for the sake of vanity, but out of curiosity."

"...I think my mother could be beautiful, in a different world. Her body is thin beneath the gray robe. She has high cheekbones and long eyelashes, and when she lets her hair down at night, it hangs in waves over her shoulders. But she must hide that beauty in Abnegation."

In terms of Erudite, they always hold the worship for science and the pursuit of new knowledge, but leave far from the original intentions.

“...Maybe Dauntless was formed with good intentions, with the right ideals and the right goals. But it has strayed far from them. And the same is true of Erudite, I realize. A long time ago, Erudite pursued knowledge and ingenuity for the sake of dong good. Now they pursue knowledge and ingenuity with greedy hearts. I wonder if the other factions suffer from the same problem."

Answering the call of duty is the bounden obligation of Dauntless, the fearless warriors spare no effort in protecting their homes, defending the city and submitting to the government. In fact, the deficiency of reason makes them the rule tool of faction in power. 
"Of course. Eric said every Dauntless was injected yesterday. So now the entire faction is brain-dead, obedient, and trained to kill. Perfect soldiers."

It is the fact that every single person has more than one aptitude due to the complexity of humanity so that it is unreasonable to classify people on the basis of one aptitude. Four, the supervisor and partner of Tris, has the tattoo of five factions.

“'I think we've made a mistake,' he says softly. 'We've all started to put down the virtues of other factions in the process of bolstering our own. I don't want to do that. I want to be brave, and selfless, and smart, and kind, and honest.' He clears his throat. 'I continually struggle with kindness.'”

There are some factionless who have poor test results that they are not selfless enough, brave enough, friendly enough, or honest enough to join any faction. As a result, they tramp the streets and suffer from discrimination. In fact, humanity is a complicated system that contains not only selflessness, fearlessness, goodness, integrity, but also greed, timidity, cruelty, and hypocrisy. Therefore, if we defy a person monotonously based on one aspect of his or her aptitude, we are bound to fail to see the whole picture of human nature.

In addition, the rule/principle/belief "faction before blood" obliterates the human nature away. No matter how developed science and technology is, family ties are the softest part of human nature and are too precious to give up. Marxist human theory tells us that one aptitude can never constitute a man because what characterizes a man is the intricate Rubik's cube of humanity. The futurist, Nice, believe that the development of science and technology is firstly a part of the development of human society, and is deeply rooted in the development of culture so as to guarantee the harmony between high-tech and high-order thinking. What's more, the evolution of technology should take the respect of humanity as the starting point and make sure that science and technology comes from the needs of human nature.

\section{Alienation of Free Will and Scientific and Technological Development}

When we try to retrospect the origin of science and technology, the starting point of the development of science and technology begins with mankind's attempts in learning more about the natural world and exploring the law of nature. And the extremely hard and bitter work provide human with every possible way to the pursuit of liberty from the constraint of mother earth. However, the progress also demonstrates that on the one hand people breathe the convenience and richness originated from the advanced science and technology; on the other hand, the highly developed science and technology also bring the restrictions, slavery and devastation to the mankind. To sustain the rapid growth of science and technology, it is required that human should all be within a certain order and occupy a position that corresponds to a specific function. In this way, human is transformed into a social function as the development of science and technology requires, and loses their ability to choose the future, enrich the personality, and the right to control their own life. In the end, they become the slave of order and function.

Hegel puts forward in his book (Book Name) that the development of free will includes three procedures: "unspecified ego", "limited ego" and "general ego" (page, year of publication). He believes that unrestricted freedom is vacuous, and violent disaster will surely come to the social and political order if we place it into real life. On the other hand, if we lose self-awareness in the development of science and technology, the liberty will break down and the free will dies.

Erudite, headed by Jeanine, regards the knowledge as the highest creed and claims that all sort of vulnerability shall be wiped off. In order to achieve her proposition, they invent "the greatest achievements" on science-aptitude test. They develops a kind of serum that contains a transmitter to link consciousness into the aptitude test program which can classify the people into five factions. Besides that, for the sake of their dream of ruling power, the Erudite implants a certain kind of serum that contains a sort of component which is capable of confusing people's mind and receiving commands from the signal source and implanting them into the Dauntless' head. Facing the coming 
slaughter carried by the controlled, the scientists show no mercy but the enjoyment of plunderage. Everybody in Dauntless is controlled by the serum except for Divergents. But Jeanine does not give up, and she calls up the crew and spares no effort to produce an improved version. And the first experiment subject is Four - the lover of Tris. Not surprisingly, Four is controlled by the scenario simulation and turns his back to his lover. The man with inflexible will abandons all his emotion, memory and consciousness, and points his gun towards the innocent people, including his lover and partner-Tris. Nobody would be delighted by that kind of toxicant apart from Jeanine and her followers because they look at the world with ruthless view and try to fulfill their appetite by unfair means or foul. As mentioned before, the freedom Erudite chases is unrestricted and unspecified, and they claim their liberty by depriving other's freedom, controlling others' behavior and thoughts. Compared with Hegel's idea about free will, the free will Erudite possesses is the unlimited one, and if this view of freedom becomes the main trend in the development of the society, the extreme terror and endless disaster will come to us sooner or later.

With the development of the society, especially the development of science and technology, if we view the individual in the world with technological reason and put individual into a certain kind of order with specified function, people will automatically turns into a machine and receives instructions that even wipe off their own thoughts. They become the man with corrupted free will. In the fiction, Abnegation and Dauntless are the typical models of that. Abnegation represents the individuals with no self-sense. "The other factions celebrate birthdays, but we don't. It would be self-indulgent." And not long before the aptitude test, an Erudite accuses an Abnegation of stealing food (not true) impolitely in front of a group of Abnegation, and nobody stands out to shield their man. As we can see, the Abnegation is too selfless to do anything for his own sake and even protect his self-esteem. Without self-awareness, there is no real self, let alone the happy life. The Dauntless, of course, is the typical faction without free will. Following the order mechanically makes them the violent killing machine for the ruler to massacre the heretic and realize the plot as they lose their subjectivity and independence as a human being and turns into a tool without free will. A big boy from Candor approaches to the verge of collapse step by step and wakes up screaming every night due to the scenario simulation, because he knows that he has no aptitude so he belongs to no faction and the fate of Factionless is much more horrible. And the freshman from Dauntless, AL evades his inward fear by committing suicide, because he knows that there is no way that he could pass the test. As plain as the nose on your face, the technology that can concrete the inner world cannot enrich the inner world of people, on the contrary, it erodes people's power of spiritual pursuit and the courage to criticize and human's value of existence is banished forever within the addled freewill.

\section{The Harmony between the Evolution of Humanity and Scientific AND TeChNOLOGiCAl DEVElopMENT}

The fiction Divergent shows us a world that is gradually dominated by the product of science and technology and full of contradiction and paradox. In order to avoid warfare and pursue the happy life, scientists intends to wipe off the "weakness" of human nature but only result in the alienation of humanity. The people who master science and technology become merciless dictators resulting from the illusion to build a faultlessly peaceful world. Modern science and technology is like an almighty god so some people regard it as the only belief; somehow, it bears the weight of the mentality and spirit. Albert Einstein gave his warning that, I do not know with what weapons World War III will be fought, but World War IV will be fought with sticks and stones. The development of society powered by the science and technology should never overlook the value rationality of the science and technology as well as the role of human nature. The development of science and technology would be ethical and humane only if it can promote and enhance the unity of the human nature system and the harmony of physical and psychological health. The coordinated development of science and technology and humanities should be the basic trend of the development of science and technology in the future, and only in this way, can the science and technology benefit mankind. 


\section{REFERENCES}

[1] Wikipedia, https://en.wikipedia.org/wiki/Rubik\%27s_Cube,2017-5-8

[2] Wipedia, https://en.wikipedia.org/wiki/Divergent_(novel)\#Reception, 2017-5-8

[3] Gleen Negley and J. Max Patrick, The Quest for Utopia, New York: Henry Schuman, 1952, 298.

[4] Ernst Cassirer, an Essay on Man, Yale University Press, 1944, 27.

[5] Veronica Roth, Divergent, HarperCollins Children's Book, 2011, 1-3; 206-207; 418; 405

\section{AUTHOR'S BIOGRAPHY}

Jiajun Xiong, I'm a graduate student for master degree in Hunan University (China). My research interest is English literature, especially bio-literature. 